\title{
Problems of School Supervision at the Basic School Level in the Hohoe Municipality of Ghana
}

\author{
Christopher Yao Dewodo ${ }^{1, *}$, Ambrose Agbetorwoka ${ }^{2}$, Pearl Wotordzor ${ }^{3}$ \\ ${ }^{1}$ St. Francis College of Education, Hohoe, Volta Region, Ghana \\ ${ }^{2}$ Akatsi College of Education, Akatsi, Volta Region, Ghana \\ ${ }^{3}$ St. Teresa's College of Education, Hohoe, Volta Region, Ghana \\ *Corresponding author: dewochris73@gmail.com
}

Received November 19, 2018; Revised January 04, 2019; Accepted February 08, 2019

\begin{abstract}
This article examines the problems associated with school supervision at the basic school level in the Hohoe Municipality of the Volta Region in Ghana. The study employed a descriptive survey method. The sample size of the study was 200. The instrument used for data collection was questionnaire. Data were analyzed using frequencies and percentages. The study revealed that two types of supervision strategies (internal and external) were found to be in use in schools in the Hohoe Municipality but not concurrently. It was also revealed that Head teachers vetted lesson plans but never supervised lesson delivery. The study recommended that all supervisory strategies (internal and external) should be adopted inasmuch as both are necessary strategies for effective supervision. Secondly, it is recommended that headteachers should follow-up into the classrooms to supervise the lesson delivery, which forms a major part of the teaching and learning process.
\end{abstract}

Keywords: basic schools, circuit supervisors, external supervision, internal supervision, supervision

Cite This Article: Christopher Yao Dewodo, Ambrose Agbetorwoka, and Pearl Wotordzor, "Problems of School Supervision at the Basic School Level in the Hohoe Municipality of Ghana." American Journal of Educational Research, vol. 7, no. 2 (2019): 133-140. doi: 10.12691/education-7-2-3.

\section{Introduction}

Education is a process, which takes place in every society. It is concerned with the development of human potentials that individuals posses at birth. Thus, education has become one of the fundamental bases on which the prosperity and future of the nation depend. Without education, no country or nation would be able to achieve social progress and prosperity, nor would the dignity and a bright future be realized. The aim of education is to provide men and women with a minimum of skills necessary for them to take their place in society and to seek for future knowledge; to provide them with a vocational training that will enable them to be self-supporting; to waken an interest in and a taste for knowledge; to make them critical thinkers, and to put them in touch with and train them to appreciate the cultural and moral achievements of humanity [1]. Consequently, formal or school education has become the means by which these objectives and aims of education in a country are achieved.

The significance of education is also epitomized in the following declaration by a renowned educationist, that in the history of mankind education has formed a continuum and a basis for the development of attitudes, values, capabilities both of knowledge and skills [2]. In view of the importance of education to the development of the country, the Ghana government spends not less than $40 \%$ of its recurrent expenditure on it [3]. Also, the inception of the Free Compulsory Universal Basic Education (FCUBE) programme in 1995 by the government has made it possible for all pupils of school going age to have access to formal education.

In spite of these efforts by the government to improve the quality of teaching and learning, it has been observed that several public schools perform far below expectation in the Basic Education Certificate Examination (BECE). In some cases, some schools even scored zero percent. This raises a great deal of concern to both the government and the public at large. The issue of low academic performance in schools despite the efforts being put in by the government to give our educational system a boost has been grossly attributed to the nature of supervision of teaching and learning at the basic school level.

\section{Statement of the Problem}

The behaviour of teachers and pupils towards the teaching and learning process in our schools these days makes one to reconsider what has been the state of supervision in the schools in the country. The opinion of the public seems to indicate that the academic performance of pupils in basic schools leaves much to be desired and these lapses are often blamed on absence of effective supervision. A casual observation of teachers in 
the Hohoe Municipality during the past two years (20162018) shows that the issue of ineffective supervision is equally grave and needs urgent attention. The Basic Education Certificate Examination (BECE) results' order of merit for Districts/Municipalities all over Ghana shows that Hohoe Municipality was among the last three Districts/Municipalities in the Volta Region for 2014/2015 academic year. The Municipality was also among the last four Districts/Municipalities in the 2015/2016 academic year. These point to the fact that there is a continuous trend of decline in the academic performance of pupils in the Municipality. Even though other factors might be contributing to this poor performance, it appears ineffective supervision plays a key role.

\section{Research Questions}

The study sought answers to the following questions:

1. What type of supervision strategies are used in the Hohoe Municipality?

2. What problems are associated with school supervision in the Hohoe Municipality?

\section{Literature Review}

\subsection{Types of Supervision}

According to [4] there are two types of supervision;

Internal and External supervisions. Internal supervision refers to supervision within the various institutions by the institutional heads while external supervision deals with supervision from the local, district, regional or national offices. Internal supervision is where the head or principal in present day public school organization is the chief school administrator in the day-to-day administration and supervision of the school [4]. On the other hand, [5] is of the view that internal supervision deals with all the activities performed by teachers and principals in the school to enhance teaching and learning. Internal supervision could be classified as that type of supervision that takes place within the school itself. Head teachers, teachers and pupils do this type of supervision. Supervision by the pupils is when from time to time prefects and class leaders ensure that assignments given to pupils/students are done, when teachers are absent from the classroom. Supervision of the pupils/students work by the teachers is very important in enhancing pupils' achievement because the teacher/pupil contact is on a daily basis more than any other contact the pupil has with other supervisors.

Teachers' supervisory duties include certain aspects of actual teaching, like making sure that the pupils pay attention while teaching is going on, evaluation of the teaching/learning process by giving pupils exercises and other forms of assignment, marking of exercises and assignments and ensuring that pupils do their corrections. These measures to a large extent enhance pupils' academic achievement. It is the duty of the teacher to also discuss bottlenecks that impede the teaching/learning process with the head teacher and external supervisors to help find solutions and thereby help improve upon the teaching/learning process. The role of the headteacher is also very important in supervision. His main duty is to ensure that adequate teaching and learning take place in the classroom. He also gives professional advice and guidance to the teachers. He is also expected to organize in service training courses for the teachers. The Headteacher is expected to observe teachers while they are teaching and also go through the exercise they do with the pupils. This should be done at least with one subject a week. As an administrator, the headteacher is to ensure that the necessary inputs like textbooks, stationery, equipment and tools are available in the school [6].

External supervision basically deals with supervision by officers from the education offices whether district, regional or national. The external supervision provided by these officers is of various types including the following:

i) Intensive visit or supervision;

ii) Brief visit or supervision; and

iii) Follow-up visit.

Intensive supervision is married to school inspection. During the course of school inspection or supervision, every effort is made to fulfil the objectives of the visit by diagnosing all the environmental conditions necessary for effective teaching and learning and giving the school staff and all concerned with the educational enterprise, the necessary guidance and advice as well as encouragement. These environmental conditions include physical facilities like classrooms, furniture and equipment, teaching/learning materials and creation of teaching/learning situations (methodology) by teachers, discipline among teachers and also among pupils and pupil/teacher relationship.

Brief supervision or visits may be considered familiarization visits whereby the officer goes to acquaint himself with the school and holding discussions with the headteacher and teachers. Follow-up visits are done after either intensive or brief visits have taken place. The basic objectives being:

i) To find out how far recommendations and suggestions have been implemented;

ii) To assist in the implementation of recommendations and suggestions;

iii) To make further recommendations where necessary $[[7] ; 4]$.

Reference [8] maintained that internal supervision is where internal measures are taken in the school by teachers to ensure the attainment of school objectives. But [6] note that internal supervision consists of action taken by teachers in the course of teaching so that objectives set out could be frequently achieved. Reference [9] saw external supervision as playing a complementary role in the supervisory process. He looks at external supervision as complementing the role and duties of the internal supervisor by providing professional advice and guidance to teachers. But [10] are of the view that the external supervisor is mainly to evaluate the effectiveness of the instructional programme in terms of what it does to the people. Reference [11] state that the duties of the external supervision include making the work of teachers more effective through such things as improved working conditions, better materials for instruction, improved methods of teaching, preparation of courses of study, supervision of instruction through direct contact with the classroom teacher. 
[8] outlined three types of supervision. These are laissez-faire supervision, cohesive supervision and supervision as a training and guidance. They explain laissez-faire supervision as a situation where teachers are allowed to do as they like with little direction and coercive supervision which involves a situation where a teacher is observed teaching and after teaching his errors are pointed out to him. They state that cohesive supervision refers to the condition whereby teachers are visited by the principal for an observation period. Following the observation of the lesson, there is a conference between the teacher and the principal in which the teacher is commended for those respects in which his lesson coincides with what the principal "know" is good teaching and pointed out to him his errors of omission and commission.

Reference [12] explained supervision as training and guidance and as a situation where instead of trying to compel teachers to follow prescribed methods; emphasis was placed upon the teaching of teachers. To them, with this type of supervision, new teachers would enter classrooms with an appreciable amount of pre-service preparation in normal schools; supervision assumed the task of continuing that training on the job. This type sees supervision as the process of teaching the teacher how to do the teaching.

Reference [13] talked about three types of supervision-full supervision, where all aspects of organization and instructional work are carefully examined; routine supervision which involves discussion with teachers on specific issues; and casual or check up visits which are usually informal. Here, the supervisor forms an opinion on what he sees. Reference [14] enumerated two types of supervision: employee-centered and job-centered. With the employeecentered supervision, supervisors focus their primary attention on the human aspects of the subordinates' problems and also endeavor to build effective work groups to achieve high performance goals. On the other hand, under the job-centered supervision, the emphasis is on the work to be done. The supervisor keeps the subordinates engaged on specified work cycles. He maintains the way in which the job is prescribed and must therefore be followed and accomplished within the given time.

\subsection{Problems of Supervision}

The behaviour of teachers towards supervision has been something that has engaged the attention of policy planners in education. Since teachers are at the centre of most of this increasing supervisory effort, their attitude towards supervision is important. Reference [15] asserted that supervision itself has a history of subservience to administrative convenience which causes teachers to view supervisors as system executioners. These inherent difficulties have led educational authorities to develop models of supervision that to them could be used as blue-prints for effective supervision.

Although there are undoubtedly many instances of well-received supervisory practice, a common response of teachers to supervision might be expressed as the suspicion that supervision is as ineffectual and at worst a harmful form of interference with the work of the teacher [16]. This opinion [16] is very common among teachers and has been a strain on the effective co-operation that should exist between the supervisor and the supervised. If teachers should view supervision as interference in their work, then it means most of the new ideas and innovation which might be given them at in-service training courses would not be implemented or if anything at all not well implemented. This has undoubtedly been one of the problems facing supervision.

Another problem confronting supervision according to [17] is that of the supervisor balancing the process of directing and controlling the supervision process. This process affects the interrelationship between supervisors and teachers. Since teachers do not have the time and opportunity to go beyond their own curriculum, it is the supervisor who normally initiates improvement of teaching and learning. In doing this, the supervisor must also be willing to hear and evaluate teachers' ideas, since supervision should also involve a process of analyzing and appraising other views.

Reference [18] stated that too many pupils per class are threatening the quality of teaching and learning and the respect of professional freedom. Reference [4] pointed out that there is a conclusive negative relationship between the extent of confidence held by teachers and the supervisor's conformity with bureaucratic practice. Reference [19] found in a study on supervision in schools that teachers attach more importance to their relationship with supervisors and that teachers consider it as a high priority to determine satisfaction. He further indicates that in Ghana, teacher have mixed feelings and attitude towards the supervisory activities of the GES Officials even though teachers acknowledge and accept the usefulness of some aspects of the supervisory process. Teachers, he says have often had cause to worry about the tendency of supervisors and inspectors often trying to find faults with the work of teachers and making unfair criticism. Teachers, according to [19] are rather of the opinion that such inspections should aim at noting deficiencies in the work of teachers and the need for inspectors and supervisors to offer teachers practical ideas, innovations and the useful suggestions that could enhance their performance. Reference [20] believed that supervision is a function that cannot be undertaken in isolation, but rather must become a co-operative venture involving the entire school. According to [21], writing on supervision maintained that headteachers should not limit their supervisory duties to only lesson notes vetting but also lesson delivery.

\subsection{Research Findings on Supervision}

Reference [22] opines that supervision is the function in schools that draws together the discrete elements of instructional effectiveness into whole school action. To him, research shows that those schools that link their instruction, classroom management and discipline with staff development, direct assistance to teachers, curriculum development, group development and action research under a common purpose achieve their objectives.

Reference [23] conducted a study of American school teachers at all levels of the elementary school on their attitudes towards supervision and concluded that:

a. Effective supervision is based on sound principles of social change and group dynamics. 
b. Teachers want supervision from Principals as well as from those persons with titles;

c. Principals do not supervise adequately;

d. The kind of help teachers want do not change significantly as the length of time in service varies; and

e. All teachers need and want supervision.

Reference [24] in his comments on effective supervision explained that to be effective, supervision must be a continuous process, a process that attempts alternatives behaviours and requires constant feedback. [20] corroborates [24] but explained further that, effective supervision also requires the supervisor to hold in-depth knowledge of the curriculum being taught, his interpersonal skills should enable him build his staff into a team and finally he must possess technical skills in observing, planning, assessing and evaluating instructional improvement. For as long as the supervisor maintains the supervisory machinery in motion and possesses the requisite skills that will enable him guide his staff, supervision will improve.

Reference [25] in a research conducted in a four-year longitudinal study of 50 elementary schools in London's miner city, found that schools with smaller student population and classes, higher socio-economic status, good physical environment and stable teaching staff had an advantage over schools without those characteristics. However, 12 key factors within the control of school were found to be crucial to school effectiveness namely:

1. The principal's leadership;

2. The Assistant Principal's involvement in instructional decision;

3. Teacher's involvement in instructional decision;

4. Consistency among teachers;

5. Structured lessons with a degree of student choice within that structure;

6. Intellectual challenging instruction;

7. A work-centred environment

8. Focused lessons, with academic work within that focus geared to individual student needs;

9. Maximum teacher-student interaction;

10. Teacher involvement including helping and visits to classrooms and attendance at meetings on student progress;

11. A positive control.; and

12. Healthy relationship.

Reference [26] explained supervision as directing or overseeing as well as watching over in order to maintain order. Reference [27] posited that supervision can be effectively carried out when materials and logistics are provided to support it. According to [28], research on effective teaching identified correlation between students' progress on standardized achievement test and teaching variables. Among the variables are the following:

i. Start off each class by reviewing homework and by renewing material covered in the previous few classes;

ii. Make the objectives of the new instructional episode clear to the students;

iii. Directly teach the content or skill that will measure on the test;

iv. After teaching the new material, assess students on the academic task. v. Maintain direct engagement by the students on the academic table.

Engaged academic time is critical variable for students' achievement; and

vi. Assign homework to increase students' familiarity with material (p.108). They conclude that assigned homework produces more learning than no homework and that higher student achievement results when comments or grades. The research on effective teaching, however does not account sufficiently for other variables that may affect the student achievement.

According to [29], school based supervision is crucial in determining what and how teaching and learning goes on in schools. This type of supervision requires that the school head should have the necessary confidence and competence to do a good job of supervising colleagues. The report also states that even though everybody in education believes that supervision is a great potential to improve education, it is not working because of lack of commitment. The concept of supervision therefore can be explained as the various activities that the heads should have of institutions perform in schools in order to improve the conditions that affect teaching and learning in schools for the achievement of the objectives of school education.

According to the [30] white paper on the Report of the Education Reform, Government accepts the recommendation that external supervision of schools should be taken out of the Ghana Education Service and transferred to the Ministry of Education, Youth and Sports. The white paper explains that the new Inspectorate of Education will be staffed at very senior levels and will undertake in accordance with its own timetable summative evaluation on a periodic basis of all first and second cycle institutions in Ghana. It will report to the Ministry of Education, Youth and Sports to ensure that its recommendations are enforced. Under this new arrangement, the Inspectorate will be empowered to set standards to be observed at the various levels in both public and private educational institutions. However, routine internal inspection of schools by Directors and Supervisors with the Regional and District Directorates of Education should continue so that standards of performance and teaching and learning are constantly maintained [30].

\section{Methodology}

The issues considered in this section include study design, the population, sample as well as the sampling procedure, the research instruments, data collection and analysis procedures.

\subsection{Study Design}

The study used the descriptive survey design. The descriptive survey is one of the best research designs that social scientists could use to gather and collect original data for studying a population too large to observe directly. The study involved the problems associated with school supervision and types of supervision strategies in use. It is to explore the perceptions of people on supervision. This 
can be measured directly through eliciting expressions of what people say $[31,32]$.

\subsection{Population and Sampling}

The target population for the study consisted of all 1844 teachers and head teachers in the 86 public basic schools and all the 10 circuit supervisors in Hohoe Municipality. Information on the population was collected from the Hohoe Municipal Education Office. The accessible population, however, comprised teachers and head teachers from 40 public schools chosen through the simple random technique.

A total of 200 respondents, comprising 150 teachers, 40 head teachers and 10 circuit supervisors were drawn for the study. The simple random sampling technique was used in selecting the 150 teachers and 20 head teachers for the study. However, the proportional random sampling technique was used to determine the number of teachers selected from each of the schools sampled. The high degree of disparity that existed among the various institutions in terms of teacher population was considered before selecting the teachers from each school. The purposive sampling technique was used in selecting the 10 circuit supervisors in the Municipality. It was used because the circuit supervisors were few and they worked in the various circuits in the Municipality. They provided information on supervision and teaching in the Municipality.

\subsection{Instruments for Data Collection}

A questionnaire was the instrument used for the collection of data. The questionnaire consisted of closed-ended items. The likert-type scale was also used. It was used to get specific responses from respondents. The questionnaire was pre-tested in four basic schools at Jasikan Education District. The testing was important because its purpose was to establish face validity and reliability of the instrument and to improve questions, format and the scales.

\subsection{Data Analysis}

The responses were edited, coded and scored. The scores were then entered into the computer using the statistical package for social sciences (SPSS) version 10.0 to derive the frequencies and the percentages for the statistical analysis of results. The frequencies and percentages were used to describe the subjects, biographic data and to answer the research questions after inferences were drawn from the data.

\section{Results and Discussion}

\subsection{Research Question 1}

What types of supervision strategies are used in schools in the Hohoe Municipality?

From Table 1, it could be noticed that 165 respondents out of 200 respondents representing $(82.5 \%)$ stated that both external and internal supervision were carried out. Twenty-five respondents representing (12.5\%) said that internal supervision strategy is in use and ten respondents $(5.0 \%)$ said that external supervision was in use in schools. From Table 1, it could be seen that there were ten respondents out of 200 who said that only external supervision was carried out in the schools. This could mean that, some headteachers have not been performing their internal supervisory roles. Twenty-five respondents also said that only internal supervision was being carried out in the schools. This implied that circuit supervisors have not been visiting these schools for supervision. However, 165 respondents stated that both external and internal supervision were being carried out in the Municipality. The finding implies that majority of the respondents are aware of the use of the two supervision strategies.

Table 1. Supervision Strategies used in Schools

\begin{tabular}{lll}
\hline Type of Strategy & Number & Percentage \\
\hline Internal & 25 & 12.5 \\
External & 10 & 5.0 \\
Both & 165 & 82.5 \\
\hline Total & 200 & 100.00 \\
\hline
\end{tabular}

Table 2. Supervision Strategies Considered Effective in Schools

\begin{tabular}{lll}
\hline Type of strategy & Number & Percentage \\
\hline Internal & 37 & 18.5 \\
External & 12 & 6.0 \\
Both & 151 & 75.5 \\
\hline Total & 200 & 100.0 \\
\hline
\end{tabular}

From Table 2, 37 (18.5\%) of the respondents considered internal supervision to be effective in schools. Twelve $(6.0 \%)$ respondents considered external supervision and as many as $151(75.5 \%)$ considered both internal and external supervision strategies as effective in schools. It could be deduced from the findings that a significant number of respondents $(75.5 \%)$ considered both internal and external supervision strategies to be effective in schools. The co-existence of these two strategies shows the complementary role of external supervision in the supervisory process. This same view is held by [9] who looks at external supervision as complementing the role and duties of the internal supervision by providing professional advice and guidance to teachers.

Table 3. Adequacy of Areas/Aspects of Headteachers' Supervision

\begin{tabular}{|c|c|c|c|c|c|}
\hline Aspects /Areas of Headteachers' & \multicolumn{2}{|c|}{ Supervision } & \multicolumn{2}{|c|}{ Adequate } & Inadequate \\
\hline & No. & $\%$ & No. & $\%$ & Total \\
\hline Lesson delivery & 61 & 30.5 & 139 & 69.5 & 100 \\
\hline School attendance of teachers & 165 & 82.5 & 35 & 17.5 & 100 \\
\hline School attendance by pupils & 112 & 56.0 & 88 & 44.0 & 100 \\
\hline Pupils responses to school bell & 73 & 36.5 & 127 & 63.5 & 100 \\
\hline Teaching and learning & 145 & 72.5 & 55 & 27.5 & 100 \\
\hline Lesson note preparation & 177 & 88.5 & 23 & 11.5 & 100 \\
\hline School discipline & 123 & 61.5 & 77 & 38.5 & 100 \\
\hline
\end{tabular}


Table 3 indicates that in lesson note preparation, out of a total number of 200 respondents, 177 representing $88.5 \%$ of the respondents stated that headteachers' internal supervision was adequate and the rest 23 respondents representing $(11.5 \%)$ noted that it was inadequate. Sixty-one (30.5\%) respondents stated that headteachers' supervision of delivery was adequate while 39 (69.5\%) respondents stated that it was inadequate. With regard to headteachers' supervision of school attendance of teachers, $165(82.5 \%)$ respondents said it was adequate and 35 $(17.5 \%)$ of them considered it as inadequate. As many as $112(56.0 \%)$ of respondents submitted that teachers' supervision of school attendance of pupils was adequate and $88(44.0 \%)$ of them stated that it was inadequate. Whereas 127 (63.5\%) of respondents stated that supervision of pupils' response to school bell was inadequate, $73(36.5 \%)$ said it was adequate. Furthermore, 145 (72.5\%) respondents were of the view that supervision of teaching and learning in schools was adequate while $55(27.5 \%)$ saw it to be inadequate. Also, 123 (61.5\%), respondents expressed the view that supervision of school discipline was adequate and 77 (38.5\%) made it clear that it was inadequate.

Judging from the above analysis, one could note that even though majority of respondents $(88.5 \%)$ stated that, headteachers' supervision of lesson note preparation was adequate, when it came to lesson delivery only 61 (30.5\%) out of a total number of $200(100 \%)$ stated that their supervision of lesson delivery was adequate. The findings revealed that even though headteachers adequately supervised lesson notes preparation, lesson delivery was not correspondingly adequately supervised by them. This finding is in line with the observations of [21] who postulated that the phenomenon whereby lesson notes are adequately supervised whereas the delivery is left unattended to is unbecoming of head teachers.

Another issue which is worth commenting on is that although majority of respondents submitted that head teachers' supervision of school attendance of pupils was adequately supervised, their supervision of how well pupils responded to the school bell was not effective. It is evident from the findings that time is not efficiently managed in these schools. This finding is in contrast with the views of [28] who observed that wise management of academic time is a critical variable for successful school work. Findings from Table 3 revealed that head teachers' supervision of teaching and learning and school discipline were adequate. This finding implies that teaching and learning is going on effectively in the schools as far as discipline in the schools is being enforced. This could be so because effective teaching and learning cannot take place without the maintenance of discipline. This finding confirms the ideas of [22] who posited that schools that build their instruction, classroom management on good discipline often achieve desired results.

\subsection{Research Question 2}

What are the problems associated with supervision?

The first item sought the views of respondents on whether the circuit supervisors paid visits to their schools once a term. Responding to this item, $21.5 \%$ stated that the issue was not applicable to them; $14.0 \%$ said the problem was very low; $20.0 \%$ of respondents indicated that the problem was low while $26.5 \%$ reported the problem was high and $18.0 \%$ noted it as very high in their schools. The finding reveals that only a little over half $(54.5 \%)$ of the respondents enjoyed the necessary external supervision. The finding therefore contradicts the views of [23] who stressed that all teachers need and want external supervision.

Respondents' views were sought on the issue of the use of attendance and log books to keep track of daily routine of teachers. Thirty-three-point five-percent (33.5\%) of the respondents did not see the use of attendance and $\log$ books as a problem existing in their schools. About $47.0 \%$ responded that the problem concerning the use of attendance and log books in their schools was very low. Sixteen percent $(16.0 \%)$ viewed the problem as low in their schools. Nevertheless, four percent $(4.0 \%)$ saw the problem of the use of Attendance and Log Books as high in their school. The findings revealed that the schools were doing well in terms of record keeping since an overwhelming number of respondents (192) noted that the Attendance and the Log Books were being used effectively in the schools.

Also, respondents were asked to express their views on whether circuit supervisors continuously fail to give prior notice of their visit to schools. Twenty-four-point-five percent $(24.5 \%)$ said the continuous failure of circuit supervisors to give prior notice in schools was very high. Twenty percent $(20.0 \%)$ indicated that it was high whereas twenty-three percent $(23.0 \%)$ and twenty-two-point-five percent $(22.5 \%)$ acknowledged it to be 'low' and "very low' respectively. Ten percent $(10.0 \%)$ however said the problem did not exist in schools. Judging from the foregoing, although a simple majority of the respondents $(55.5 \%)$ considered the failure of the circuit supervisors to give prior notice of their visits to schools as not so much a problem, the data present a picture of it as a menace to the teachers. Relatively, its high rate $(44.5 \%)$ shows that it poses a threat to effective supervision in school. The views of the minority differ from the observation of [7] who indicated that the role of circuit supervisors have now changed to working co-operatively with the teachers to create favourable circumstances for teaching and learning. His assertion is manifested to some extent by the cooperation of circuit supervisors and teachers despite the fact that some of the schools have not yet experience this change.

Table 4. Supervisor-Based Problems Associated with Supervision

\begin{tabular}{|c|c|c|c|c|c|c|}
\hline \multirow[b]{2}{*}{ Problems } & \multicolumn{6}{|c|}{ Responses in Percentages } \\
\hline & Not Applicable & Very Low & Low & High & Very High & Total \\
\hline The circuit supervisor visits the school once a term & 21.5 & 14.0 & 20.0 & $26 . .5$ & 18.0 & 100.0 \\
\hline $\begin{array}{l}\text { Use of Attendance and Log Books to keep track of the daily routine of } \\
\text { teachers }\end{array}$ & 33.5 & 46.5 & 16.0 & 4.0 & 0.0 & 100.0 \\
\hline $\begin{array}{l}\text { Continuous failure of circuit supervisors to give prior notice of their } \\
\text { visits to schools }\end{array}$ & 10.0 & 22.5 & 23.0 & 20.0 & 24.5 & 100.0 \\
\hline $\begin{array}{l}\text { Supervisors demonstrate very little or no knowledge about teaching and } \\
\text { learning }\end{array}$ & 40.0 & 41.5 & 12.5 & 3.0 & 3.0 & 100.0 \\
\hline
\end{tabular}


The item that follow sought the views of respondents on whether supervisors demonstrated very little or no knowledge about teaching and learning. Responding to this item, $40 \%$ indicated that the issue was not applicable to them. $41.5 \%, 12.5 \%$ also responded that the problem was very low, and low respectively, $3.0 \%$ however noted that the problem was high while another $3.0 \%$ saw it as very high in their schools. The finding shows that a majority (94\%) of the respondents noted that supervisors demonstrated competency in pedagogy. These findings agree with the views of [20] and also corroborate those of [24] who explained that effective supervision requires the supervisor to have in-depth knowledge of curriculum being taught.

\section{Conclusion}

The results of the study suggest that both internal and external supervision strategies were carried out effectively in schools within the Hohoe Municipality. However, there were few challenges like failure of some circuit supervisors to give prior notice of their visits to the schools and head teachers lacking in the supervision of lesson delivery even though they vetted lesson plans adequately. These, however, could be eliminated or at least, minimized through the collaborative efforts of both teachers and the supervisory institutions. Finally, it must be stated that the study supported most of the literature previously cited and refuted others as well.

\section{Recommendations}

1. It was found out that lesson notes preparation was adequately supervised by headteachers but they were lacking in the supervision of lesson delivery. It is recommended that headteachers should follow-up into the classrooms to supervise the lesson delivery, which forms a major part of the teaching and learning process.

2. It was found out that some schools were either supervised only internally or only externally. It is suggested that the other supervisory strategies lacking in such schools should be adopted to complement the one in use inasmuch as both are necessary strategies for effective supervision.

3. The study also revealed that some circuit supervisors did not give prior notice of their visitations to schools, it is recommended that in this era of clinical supervision, teachers should be duly informed by external supervisors before they come to their schools. More so, supervision should not aim at finding fault with the work of the teacher but rather focus on fact-finding.

4. With regard to the problems militating against effective supervision, it is recommended that the Ghana Education Service (GES) should beef up its efforts at providing logistical support for schools in the Municipality. Apart from that, workshops and seminars should be organized periodically to sensitize teachers on the usefulness of supervision in an effort to curb the uncooperative and apathetical attitudes of teachers towards supervision.

\section{References}

[1] Harris, B.M., (1975). Supervisory behaviour in education. Englewood Cliffs, NJ: Prentice Hall.

[2] Dondieu, C.K. (2001). Guide notes to the study of education. Cape Coast, Ghana: Catholic Press.

[3] Ministry of Finance (2017). Ghana National Budget. Accra: Institute of Economic Affairs.

[4] Neagley, R.L.S., \& Evans, N.D. (1970). Handbook for effective supervision ofinstruction. Englewood Cliffs, NY: Prentice Hall Inc.

[5] Wanzare, Z.O. (2011). Re-thinking school-university collaboration.: Agenda for $21^{\text {st }}$ century. Educational Research and Reviews, 6(22) 1036-1045. 2011

[6] Alimi, P. \& Akinfolarin, C.A. (2012). Impacts of selected modes of institutional supervision activities on student academic performance in Senior Secondary Schools in Orido State, Nigeria. Department of Education.

[7] Asiedu-Akrofi, K. (1978). School organization in modern Africa. Tema: Ghana Publishing Corporation.

[8] Elsbree, W. S. \& McNally, H.J. (1967). Elementary school administration and Supervision. New York: Litton Educational Publishing Inc.

[9] Halpin, A. W. (1966). The leadership behavior of school superintendents: The School Community Development Study. California: Wardsworth Publishing Company.

[10] Beach, D.M. \& Reinhartz, J. (2000). Supervisory Leadership: Focus on Instruction. Boston: Allyn and Bacon.

[11] Sergiovanni, T.T., \& Starratt, R.J. (2007). Supervision: A redefinition $\left(8^{\text {th }}\right.$ ed.). New York: Mc Graw-Hill Companies.

[12] Blase, J. (2004). Handbook of instructional leadership. How successful principalspromote teaching and learning $\left(2^{\text {nd }}\right.$ Ed.). California: Corwin Press.

[13] Musaazi, J. C.S. (1985). The theory and practice of educational administration. London: Macmillian Publishers Ltd.

[14] Likert, R. (1961). The human organisation, its management and value.New York: McGraw-Hill.

[15] Eye, G.G. (1975). Problems in supervision: A phase of administration. New York: Harper and Row Publishers.

[16] Mosher, J \& Purpel, M. (1972). School supervision. London: Macmillan Publishers.

[17] Sullivan, S., \& Glanz, J. (2005). Supervision that improves teaching (2nd ed.). London: Corwin Press.

[18] Naaso, P. (1995). Educational Reforms in Ghana. Accra: Universities Press.

[19] Bame, K.N. (1991). Teacher motivation and retention in Ghana. Accra: Universities Press.

[20] Glickman, C.D., Gordon, S.P. \& Ross-Gordon, J.M. (1995) Supervision of Instruction:A development approach. Boston: Allyn and Bacon.

[21] Wanzare, Z.O. (2011). Journal of Educational Management Administration and Leadership. 40 (2) 188-216.

[22] Mackenzie, D.E. (1983). Research for school improvement. An approach of some recent trendsin educational research. Boston: Houghton Mufflin Company.

[23] Glatthorn, A.A. (2007). Co-operative Professional Development Peer Centred Options for Teacher Growth. New York: Educational Leadership.

[24] Spanjer, R.A. (1975). Competency-based student-teacher supervision. Boston: Houghton Mufflin Company.

[25] Mortimore, P., Simmons, P., Stoll, L., Lewis, D \& Ecob, R. (1988). School matters. Berkley C.A.: University of California.

[26] Frazer, K. (2000).Supervisory Behaviour and Teacher Satisfaction. Journalof Educational Administration 18 (2) P224-227.

[27] Wanzare, Z. O. (2002). Rethinking School Inspection in the Third World: The Case of Kenya. Educational Management, Administration \& Leadership, 30(2), 213-229.

[28] Sergiovanni, T.T., \&Starratt, R.J. (1993). Supervision: A redefinition. New York: McGraw-Hill Inc.

[29] Government of Ghana, (1994). Education review committee report. Accra:Ministry of Education and Sports. 
[30] Government of Ghana (2004). White paper on the report of the education reform review committee. Accra: Ministry of Education, Youth and Sports.

[31] Ary, D., Jacobs, L \& Razavieh, A. (1990). Introduction to research in education ( $4^{\text {th }}$ ed.). Fortworth: Holt, Rinehart and Winston, Inc.

[32] Babbie, E. (1990). Survey research methods (2 ${ }^{\text {nd }}$ ed.) Belmont, California: Wardsworth Publishing Company. 